\title{
PCR assay for the detection of Campylobacter in marinated and non-marinated poultry products
}

Katzav, Marianne; Isohanni, Pauliina; Lund, Marianne; Hakkinen, Marjaana; Lyhs, Ulrike

Published in:

Food Microbiology

Link to article, DOI:

10.1016/j.fm.2008.05.010

Publication date:

2008

Document Version

Publisher's PDF, also known as Version of record

Link back to DTU Orbit

Citation (APA):

Katzav, M., Isohanni, P., Lund, M., Hakkinen, M., \& Lyhs, U. (2008). PCR assay for the detection of Campylobacter in marinated and non-marinated poultry products. Food Microbiology, 25(7), 908-914. https://doi.org/10.1016/j.fm.2008.05.010

\section{General rights}

Copyright and moral rights for the publications made accessible in the public portal are retained by the authors and/or other copyright owners and it is a condition of accessing publications that users recognise and abide by the legal requirements associated with these rights.

- Users may download and print one copy of any publication from the public portal for the purpose of private study or research.

- You may not further distribute the material or use it for any profit-making activity or commercial gain

- You may freely distribute the URL identifying the publication in the public portal 


\title{
PCR assay for the detection of Campylobacter in marinated and non-marinated poultry products
}

\author{
Marianne Katzav ${ }^{a}$, Pauliina Isohanni ${ }^{a}$, Marianne Lund ${ }^{b}$, Marjaana Hakkinen ${ }^{c}$, Ulrike Lyhs ${ }^{a, *}$ \\ ${ }^{a}$ Ruralia Institute, University of Helsinki, Kampusranta 9C, FI-60320 Seinäjoki, Finland \\ b National Veterinary Institute, Technical University of Denmark, Hangoevej 2, DK-8200 Aarhus N, Denmark

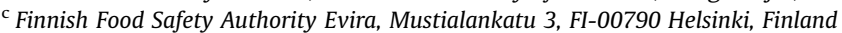

\section{A R T I C L E I N F O}

\section{Article history:}

Received 5 March 2008

Received in revised form

18 May 2008

Accepted 22 May 2008

Available online 21 July 2008

\section{Keywords:}

Campylobacter

Poultry products

Retail

PCR

\begin{abstract}
A B S T R A C T
During a period of 9 months, 194 marinated and non-marinated poultry products were collected from retail shops in a defined area in Western Finland and tested for Campylobacter spp. using a conventional enrichment culture and Polymerase Chain Reaction (PCR) method. For marinated poultry products, the study involved modification of a commercial DNA isolation method. Using either a conventional culture or PCR method, a total of $25(12.9 \%)$ of all investigated samples were Campylobacter positive. In marinated poultry products, Campylobacter was detected at a prevalence of $21.1 \%$ and $9.5 \%$ in turkey and chicken products, respectively. In August, there was a peak with $28.9 \%$ positive Campylobacter samples. Campylobacter inoculation tests were carried out to test the detection limit of both methods. The PCR method used is faster than microbiological analyses. However, enrichment of the samples is necessary due to the low occurrence of Campylobacter spp. in retail Finnish poultry products.
\end{abstract}

(c) 2008 Elsevier Ltd. All rights reserved.

\section{Introduction}

Campylobacter is the most common cause of bacterial enteritis worldwide (Rautelin and Hänninen, 2000; Samuel et al., 2004; Schönberg-Norio et al., 2004, 2006). In Finland, according to the National Infectious Disease Registry, the incidence of campylobacteriosis has increased steadily reaching 4003 and 3439 infections in 2005 and 2006, respectively, with 65 human cases/ 100,000 inhabitants in 2006 (Anonymous, 2005, 2006a). These high figures make Campylobacter nowadays the leading cause of bacterial enteric infections in Finland. Epidemiological studies have underlined handling and consumption of undercooked poultry meat as one of the most important sources of human campylobacteriosis (Evans et al., 2003; Potter et al., 2003; Luber and Bartelt, 2007). Limited studies have been published on the prevalence of Campylobacter in poultry meat at the Finnish retail level. Hänninen et al. (2000) studied the prevalence of Campylobacter in poultry products in the Helsinki area between June and September from 1996 to 1998 and found 12-21\% Campylobacter positive samples in each year studied. In summer 2004, the percentages of Campylobacter positive fresh broiler and turkey meat at the Finnish retail level were $20.2 \%$ and $19.2 \%$, respectively (Anonymous, 2006a-c). In contrast, studies from other countries

\footnotetext{
* Corresponding author. Tel.: +35864213 319; fax: +358641213310.

E-mail address: ulrike.lyhs@helsinki.fi (U. Lyhs).
}

report a high occurrence of Campylobacter at the retail level, for example, $71.3 \%$ in the UK (Philipps, 1998), 79.4\% in Spain (Mateo et al., 2005) and 64.7\% in Japan (Sallam, 2007).

There is a wide variety of poultry products available on the Finnish retail market including fresh and modified-atmospherepackaged (MAP) products with or without spices. Approximately $80 \%$ of these products are sold marinated (Björkroth, 2005). Marinating, in this context, means salting and mixing the meat with water-oil-based, spiced sauces. High $\mathrm{NaCl}$ concentration, low $\mathrm{pH}$ and the addition of different spices to the marinade prevent the growth of spoilage bacteria, thus increasing the shelflife of the meat products. However, marinating poultry meat does not decrease pathogenic bacteria such as Campylobacter (Evans et al., 1998; Perko-Mäkelä et al., 2000).

Since the popularity and the variety of marinated poultry products in Finland is increasing rapidly every year, reliable methods for the detection of Campylobacter in these products are of interest to laboratories in routine work and research. Traditional conventional culture methods include enrichment and plating steps followed by isolation of the bacterium and biochemical identification of the isolate. These methods are laborious, time consuming and costly. Recently designed polymerase chain reaction (PCR) methods have been found to be faster, more specific and sensitive for the detection of Campylobacter in naturally contaminated retail samples (Denis et al., 2001; Wong et al., 2004; Mateo et al., 2005; Sallam, 2007). However, several substances in foods can be inhibitory for the PCR. Lilja and 
Hänninen (2001) reported problems in the preparation of marinated chicken samples prior to PCR analysis. Thus, it is important to neutralize such substances by using effective DNA purification protocols or PCR facilitators.

The aim of the present study was to determine the occurrence of Campylobacter in naturally contaminated poultry products at the retail level in Western Finland. Special attention was paid to the wide variety of marinated products available on the market. For the detection of Campylobacter, a PCR assay has been compared with the conventional culturing method. The original protocol for the DNA isolation using a commercial kit was modified.

\section{Materials and methods}

\subsection{Sampling}

A total of 194 raw chilled poultry products (136 chicken samples, 56 turkey samples and two samples including both chicken and turkey meat) were randomly selected between January and September 2006 from different local retail shops in a defined area in Western Finland. All products were packed in Finland, but in 11, nine and two samples, the meat originated from Denmark, Brazil and France, respectively. All samples were transported immediately to the laboratory and kept at $4 \pm 3{ }^{\circ} \mathrm{C}$ until being analyzed within $24 \mathrm{~h}$ of purchase. Between January and June, ten samples were analyzed once a month and from July to September, 15 samples were analyzed three times a month.

\subsection{Sample description}

The product types and the numbers of samples in each group are presented in Table 2. According to the manufacturers, the meat concentration in all samples varied from $66 \%$ to $100 \%$ and the salt concentration from $0.6 \%$ to $1.6 \%$. The term natural product in this study refers to a non-marinated product of $100 \%$ meat without any added substances. Lightly salted products are those with a meat content of $66-80 \%$, a salt concentration of $1 \%$ and the addition of water, glucose and food additives. The term "marinated" includes all products with an oil- and/or water-based marinade and a blend of spices with $0.9-1.6 \%$ salt. In 47 of all 136 marinated products, honey was the most popular flavor in the marinade. Other common flavors were citrus fruits, peppers, herbs, garlic and barbecue spice. The term "spiced" refers to products with blended spices, salt $(0.8-1.4 \%)$ and often other ingredients such as flour and breadcrumb rubbed onto the meat surface. The meat content in the marinated and spiced products varies from $66 \%$ to $97 \%$ and several food additives like stabilizers, antioxidants, acidity balancing agents, preservatives, thickening and flavoring agents are added. These product types also contain maltodextrin, yeast extract and other flavor enhancers. In addition, modified starch, barley or wheat may be added. All the products were packed under a modified atmosphere consisting of carbon dioxide and nitrogen in different proportions and had a shelf life of up to 10 days.

\subsection{Culture method for the detection of Campylobacter in poultry samples}

Microbiological analyses of the samples were based on a modified method of the National Committee of Food Analyses (2007).

Each sample was aseptically removed from the package and placed in a Stomacher bag (Seward BA6041, Worthing, UK). Equal amounts of a weighed sample and Buffered Peptone Water (BPW) (LAB46, LabM, Lancashire, UK) were mixed with a minimal amount of $300 \mathrm{~g}$ of meat in $300 \mathrm{ml}$ of BPW (LabM). The bag was shaken manually for $3 \mathrm{~min}$. For the enrichment, $25 \mathrm{ml}$ of the suspension was re-suspended in $225 \mathrm{ml}$ of Bolton broth (LAB135, LabM) with 5\% lysed horse blood and selective supplement (LX132, LabM) and incubated in a microaerobic atmosphere (5\% $\mathrm{O}_{2}, 10 \% \mathrm{CO}_{2}, 85 \% \mathrm{~N}_{2}$ ), generated by CampyGen ${ }^{\mathrm{TM}}$ (Oxoid CN0035) at $42{ }^{\circ} \mathrm{C}$ for $24 \mathrm{~h}$. A loopful of the enrichment culture $(10 \mu \mathrm{l})$ was streaked on an modified charcoal cefoperazone deoxycholate agar plate (mCCDA) (CM 739, Oxoid, Basingstoke, UK) supplemented with SR 155 (Oxoid) and incubated microaerobically at $42^{\circ} \mathrm{C}$ for 48 h. Presumptive Campylobacter colonies on mCCDA plates were further identified according to the method of the National Committee of Food Analyses (2007). To test their ability to grow aerobically, they were subcultured onto blood agar plates (CASO agar, Casein-Peptone Soymeal-Peptone, Merck, Darmstadt, Germany with $5 \%$ bovine blood) and incubated aerobically at $37{ }^{\circ} \mathrm{C}$ for $24 \mathrm{~h}$. Strains were stored at $-80^{\circ} \mathrm{C}$ in Brucella broth (Scharlau Chemie, Barcelona, Spain) containing 15\% glycerol.

\subsection{PCR method for the detection of Campylobacter in poultry samples}

For the PCR sample, $1.5 \mathrm{ml}$ of the rinsing fluid was centrifuged at $1000 \mathrm{rpm}$ for $8 \mathrm{~min}$ at $4{ }^{\circ} \mathrm{C}$. The middle aqueous layer was removed carefully to avoid any fat and placed into an unused Eppendorf tube. After centrifugation at $13,000 \mathrm{rpm}$ for $8 \mathrm{~min}$ at $4{ }^{\circ} \mathrm{C}$, the supernatant was removed carefully and the pellet was frozen at $-70^{\circ} \mathrm{C}$.

For the PCR of the enriched sample, $1 \mathrm{ml}$ of enrichment culture was collected after $24 \mathrm{~h}$ incubation. The subsample was centrifuged at $13,000 \mathrm{rpm}$ for $8 \mathrm{~min}$ at room temperature. The supernatant was removed carefully and the pellet was frozen at $-70^{\circ} \mathrm{C}$.

\subsubsection{DNA isolation}

DNA isolation from the frozen pellet was carried out using a DNA isolation kit MagneSil ${ }^{\circledR}$ KF (MD1460, Genomic System, Promega, Madison, WI, USA) with a Dynal MPC ${ }^{\mathbb{R}}-S$ magnetic stand (Dynal Biotech, Oslo, Norway). The instructions of the supplier were modified and optimized for DNA isolation by hand using a magnetic stand. A $200 \mu \mathrm{l}$ lysis buffer and $75 \mu \mathrm{l}$ magnetic beads were added to an Eppendorf tube containing the pellet. The mixture was vortexed vigorously four times during a 5 min period at room temperature before placing the tube in a magnetic stand with the magnet for $30 \mathrm{~s}$. The magnet was taken out after the liquid was removed from the tube. The particles were washed twice with $185 \mu \mathrm{l}$ of salt washing buffer and twice with $200 \mu \mathrm{l}$ of ethanol washing buffer. The tube was then placed in a $72{ }^{\circ} \mathrm{C}$ heat block for $5 \mathrm{~min}$ with an open lid for ethanol dehydration. The particles were re-suspended in $100 \mu \mathrm{l}$ of sterile water and replaced in a $72{ }^{\circ} \mathrm{C}$ heat block for another $5 \mathrm{~min}$ with the lid closed. The tube was mixed with vortex and placed in the magnetic stand for $30 \mathrm{~s}$. The liquid was removed from the tube to be frozen at $-20^{\circ} \mathrm{C}$.

\subsubsection{PCR assay}

The detection of Campylobacter in the samples was based on amplification of the 16S rRNA gene (Linton et al., 1996) using two sets of oligonucleotide primers. The first set was C412F $5^{\prime}-\mathrm{GGA}$ TGA CAC TTT TCG GAG C-3' (Linton et al., 1996) and 16S rRNAcampR2 5'-GGC TTC ATG CTC TCG AGT T-3' as described by Lund et al. (2004). The second set was MD16S1, 5'-ATC TAA TGG CTT AAC CAT TAA AC-3' and MD16S2, 5'-GGA CGG TAA CTA GTT TAG TAT T-3' as described by Denis et al. (1999). For detection of the internal control the primers Yers F8 5'-CGA GGA GGA AGG GTT 
Table 1

List of strains used for validation of specificity of the 412F-16S rRNA-campR2 primer set

\begin{tabular}{|c|c|c|c|}
\hline Species & Strain & Species & Strain \\
\hline Campylobacter jejuni & CCUG 11284 & Campylobacter & CCUG 18267 \\
\hline Campylobacter jejuni & CCUG 24567 & Campylobacter lari & CCUG 15035 \\
\hline Campylobacter jejuni & CCUG 10940 & Campylobacter lari & CCUG 12774 \\
\hline Campylobacter jejuni & CCUG 12778 & Campylobacter lari & CCUG 18294 \\
\hline Campylobacter jejuni & $\mathrm{DCC}^{\mathrm{a}} 42$ & Campylobacter lari & DCC 50 \\
\hline Campylobacter jejuni & DCC 43 & Campylobacter lari & DCC 29 \\
\hline Campylobacter jejuni & DCC 44 & Campylobacter lari & DCC 33 \\
\hline Campylobacter jejuni & DCC 45 & Campylobacter helveticus & CCUG 30682 \\
\hline Campylobacter jejuni & DCC 47 & Campylobacter helveticus & CCUG 30683 \\
\hline Campylobacter jejuni & DCC 48 & Campylobacter helveticus & CCUG 30563 \\
\hline Campylobacter jejuni & DCC 49 & Campylobacter helveticus & CCUG 30564 \\
\hline Campylobacter jejuni & DCC 52 & Campylobacter helveticus & CCUG 30565 \\
\hline Campylobacter jejuni & DCC 22 & Campylobacter helveticus & CCUG 30566 \\
\hline Campylobacter jejuni & DCC 27 & Campylobacter helveticus & CCUG 34016 \\
\hline Campylobacter jejuni & DCC 34 & Campylobacter hyointestinalis & CCUG 14169 \\
\hline Campylobacter jejuni & DCC 40 & Campylobacter hyointestinalis & CCUG 34538 \\
\hline Campylobacter jejuni & DCC 41 & Campylobacter sputorum & CCUG 37579 \\
\hline Campylobacter coli & CCUG 11283 & Campylobacter concisus & CCUG 13144 \\
\hline Campylobacter coli & CCUG 33450 & Campylobacter curvus & CCUG 13146 \\
\hline Campylobacter coli & DCC 36 & Campylobacter mucosalis & CCUG 6822 \\
\hline Campylobacter coli & DCC 37 & Campylobacter fetus & CCUG 6825A \\
\hline Campylobacter coli & DCC 38 & Arcobacter cryaerophilis & CCUG 17801 \\
\hline Campylobacter coli & DCC 39 & Arcobacter skirrowii & CCUG 10374 \\
\hline Campylobacter coli & DCC 46 & Arcobacter butzleri & CCUG 30485 \\
\hline Campylobacter coli & DCC 51 & Helicobacter pylori & DCC 35 \\
\hline Campylobacter coli & DCC 28 & Helicobacter pullorum & DCC 53 \\
\hline Campylobacter coli & DCC 18 & Enteroccocus faecalis & CCUG 19916 \\
\hline Campylobacter upsaliensis & CCUG 23626 & Escherichia coli & CCUG 17620 \\
\hline Campylobacter upsaliensis & CCUG 14913 & Streptococcus aureus & CCUG 17621 \\
\hline Campylobacter upsaliensis & CCUG 24571 & Staphyloccus bovis & CCUG 17828 \\
\hline Campylobacter upsaliensis & CCUG 24803 & Salmonellatyphimurium & DVI- $\AA^{\mathrm{b}} 19$ \\
\hline Campylobacter upsaliensis & CCUG 23017 & Salmonella enteritidis & DVI-Å20 \\
\hline Campylobacter upsaliensis & CCUG 20818 & Proteus mirabilis & CCUG 34293 \\
\hline Campylobacter lari & CCUG 23947 & Bordetella bronchiseptica & DVI-Å50 \\
\hline Campylobacter lari & CCUG 20575 & Citrobacter freundii & DVI-Å22 \\
\hline
\end{tabular}

a DVI culture collection.

b DVI- $\AA$ : In house reference strain.

AAG TG-3' and Yers R10 5'-AAG GCA CCA AGG CAT CTC TG-3' according to Gibello et al. (1999) slightly modified were used. All the primers were synthesized by Oligomer Oy (Helsinki, Finland).

\subsubsection{PCR amplification}

The PCR conditions used in the present study are described by Lund et al. (2003) with a few modifications. Briefly, the PCR amplification was performed in $50 \mu \mathrm{l}$ volumes containing $5 \mu \mathrm{l}$ of the DNA, $25 \mu \mathrm{l}$ of a PCR master mix (Promega, Madison, WI, USA), $1 \mu \mathrm{l}$ of a $25 \mathrm{mM} \mathrm{MgCl}_{2}$ solution, $0.5 \mu \mathrm{l}$ of a $10 \mathrm{mg} \mathrm{ml}^{-1} \mathrm{BSA}$ solution (New England Biolabs, Ipswich, MA, USA), 20 pmol of each of the Campylobacter primers and 5 pmol of each of the internal control primers.

The PCR was performed in a Peltier Thermal Cycler (PTC-200; MJ Research Inc., Watertown, MA, USA) and the conditions were one cycle of $95^{\circ} \mathrm{C}$ for $2 \mathrm{~min}, 58^{\circ} \mathrm{C}$ for $1 \mathrm{~min}, 72^{\circ} \mathrm{C}$ for $1 \mathrm{~min}$, followed by 34 cycles of $95{ }^{\circ} \mathrm{C}$ for $15 \mathrm{~s}, 58^{\circ} \mathrm{C}$ for $40 \mathrm{~s}$ and $72{ }^{\circ} \mathrm{C}$ for $40 \mathrm{~s}$. The last elongation step lasted $5 \mathrm{~min}$. The PCR product was loaded onto a $2 \%$ agarose gel $\left(1.35 \%\right.$ SeaKem ${ }^{\circledR}$ LE Agarose and 0.65\% NuSieve ${ }^{\circledR}$ GTG Agarose, Cambrex Bio Science, Rockland, ME, USA) containing $0.1 \mu \mathrm{g} \mathrm{ml}^{-1}$ ethidium bromide. A DNA molecular weight marker $100 \mathrm{bp}$ low ladder (P1473, Sigma-Aldrich, Saint Louis, MO, USA) was included in each gel. The gel was photographed under UV light (Alpha DigiDoc, Alpha Innotech, San Leandro, CA, USA). The PCR reaction for each sample was performed 1-3 times with each primer set and considered positive if both primer sets gave a distinct band of the right size ( $857 \mathrm{bp}$ ) or at least one primer set gave a positive reaction twice.
Samples with no internal control band were run again using a tenfold dilution of DNA.

\subsubsection{Control strains}

For PCR, Campylobacter jejuni EELA 49 strain (isolated from a Finnish broiler carcass) was used as a positive control. As negative controls, sterile water in the PCR method and Bolton broth (LabM) in the culture method were used. An internal control was added to the mastermix. Briefly, DNA from the bacterium Yersinia ruckeri (DVI-Å83) was isolated using the MagneSil KF (MD1460, Genomic System, Promega, Madison, WI, USA) as described above. Approximately $25 \mathrm{pg}$ Y. ruckeri DNA was added to the mastermix before aliquoting into tubes (Lund et al., 2004; Lund and Madsen, 2006).

The strains used for validation of specificity of the C412F-16S rRNA-campR2 primer set and their sources are listed in Table 1. Strains were stored at $-80^{\circ} \mathrm{C}$ in brain heart infusion broth (Difco, Detroit, MI, USA) containing $20 \%$ glycerol. For testing the specificity of the primers used in the assay, DNA was isolated directly from the storage medium by centrifugation of $0.1 \mathrm{ml}$ of the medium at $15,870 \mathrm{rpm}$ for $7 \mathrm{~min}$ and then the pellet was subjected to DNA extraction as described before. Approximately 1 ng of DNA was used per PCR.

\subsubsection{Comparison of the detection limit between the culture and PCR method}

A tenfold dilution series of a $C$. jejuni broth culture was used to determine the detection limit of the culture and the PCR method. 
Table 2

Types of Finnish retail poultry products and Campylobacter positive samples

\begin{tabular}{|c|c|c|c|c|c|}
\hline \multirow[t]{2}{*}{ Product type } & \multirow{2}{*}{$\begin{array}{l}\text { No. of samples } \\
\text { positive by culture/ } \\
\text { PCR }\end{array}$} & \multicolumn{4}{|c|}{ No. of samples positive ${ }^{a} /$ No. of samples tested } \\
\hline & & $\begin{array}{l}\text { Slices and } \\
\text { barbecue sticks }\end{array}$ & $\begin{array}{l}\text { Breast fillet and } \\
\text { fillet steaks }\end{array}$ & $\begin{array}{l}\text { Breasts, legs } \\
\text { drumsticks and } \\
\text { wings incl. bones } \\
\text { and skin }\end{array}$ & All \\
\hline Natural & & $0 / 3$ & $2 / 4$ & $2 / 8$ & $4 / 15$ \\
\hline Lightly salted & & $0 / 1$ & $0 / 0$ & $0 / 0$ & $0 / 1$ \\
\hline Spiced & & $0 / 1$ & $0 / 6$ & $7 / 18$ & $7 / 25$ \\
\hline Marinated & & $3 / 51$ & $1 / 24$ & $5 / 20$ & $9 / 95$ \\
\hline Total chicken samples & & $3 / 56$ & $3 / 34$ & $14 / 46$ & $20 / 136$ \\
\hline Natural & & $0 / 8$ & $0 / 7$ & $0 / 0$ & $0 / 15$ \\
\hline Lightly salted & & $0 / 0$ & $0 / 1$ & $0 / 0$ & $0 / 1$ \\
\hline Spiced & & $0 / 0$ & $0 / 1$ & $0 / 0$ & $0 / 1$ \\
\hline Marinated & & $4 / 19$ & $0 / 20$ & $0 / 0$ & $4 / 39$ \\
\hline Total turkey samples & & $4 / 27$ & $0 / 29$ & $0 / 0$ & $4 / 56$ \\
\hline Marinated & & $1 / 2$ & $0 / 0$ & $0 / 0$ & $1 / 2$ \\
\hline Total mixed chicken and turkey samples & & $1 / 2$ & $0 / 0$ & $0 / 0$ & $1 / 2$ \\
\hline Total samples & $18 / 24$ & $8 / 85$ & $3 / 63$ & $14 / 46$ & $25 / 194$ \\
\hline
\end{tabular}

${ }^{a}$ No. of samples tested positive by microbiological method and/or PCR method.

$100 \mu \mathrm{l}$ of each dilution from $10^{-1}$ to $10^{-7}$ was plated out for counting the colony forming units (cfu) of the stock solution. Seven samples of $100 \mathrm{~g}$ poultry meat slices and $42 \mathrm{~g}$ of plain marinade were placed in a Stomacher bag (Seward BA6041). One $\mathrm{ml}$ of each dilution of $C$. jejuni broth culture was mixed with $100 \mathrm{ml}$ of BPW (LabM) and this mixture was added to the samples. All samples were subjected to the cultural detection and PCR procedures as described above. This procedure was repeated once.

\subsection{Data management and calculations}

For data management and calculations, Microsoft ${ }^{\circledR}$ Excel 97 SR 2 and SAS ${ }^{\circledR}$ Systems vers. 8 (Cary, NC, USA) were used. The level of agreement according to precision was expressed as the kappa statistic, defined as the proportion of potential agreement beyond chance exhibited by two tests. Diagnostic specificity was calculated as: $d /(b+d)$ where $d$ is the number of samples negative both by PCR and by culture and $b$ is the number of samples positive by PCR, but negative by culture. The level of agreement between two tests was calculated as: $(a+d) / n$, where $a$ is the number of samples positive both by PCR and by culture, $d$ is the number of samples negative by both methods and $n$ is the total number of samples under examination (Smith, 1995; Martin et al., 1997).

\section{Results}

\subsection{Prevalence of Campylobacter in poultry products}

Using either a conventional culture or PCR method, a total of $25(12.9 \%)$ of 194 investigated samples were Campylobacter positive (Table 3 ). The isolation rates from the different product types are listed in Table 2. Out of 136 chicken and 56 turkey products, $20(14.7 \%)$ and four $(7.1 \%)$ samples respectively were Campylobacter positive. One of the two mixed chicken and turkey samples was positive for Campylobacter. Campylobacter was detected in four (13.3\%) of the 30 natural and $14(10.3 \%)$ of the 136 marinated poultry products. Seven $(26.9 \%)$ of the 26 spiced products were positive, all being chicken with skin and bone. No Campylobacter was detected in two lightly salted products. The occurrence of Campylobacter in chicken slices and barbecue sticks

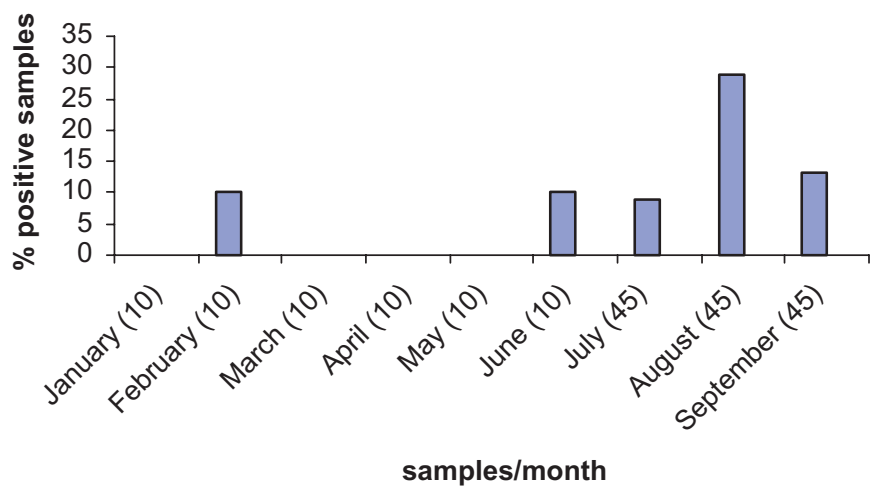

Fig. 1. Monthly distribution of Campylobacter positive samples in Finnish retail poultry products from January to September 2006. The numbers in parenthesis represent the number of samples taken per month.

was $9.4 \%$, in chicken breast fillets $4.7 \%$ and chicken products with skin and bone $30.4 \%$. Campylobacter was not detected in any of the 22 poultry products with meat of foreign origin.

In August, there was a peak with a $28.9 \%$ prevalence of Campylobacter in 45 investigated samples (Fig. 1). Between January and May, Campylobacter was detected in only one of 50 samples.

\subsection{Comparison of the culture and PCR method}

Eighteen (9.3\%) of 194 samples were positive using the conventional culturing method and $24(12.4 \%)$ were positive using the PCR method for Campylobacter (Table 3 ). The results of the culture and PCR were concordant in 186 samples, representing $96.4 \%$ of the samples. One sample (1/18), gave a negative result for PCR when the result of the culture method was positive. Seven samples gave a positive result when the culture result was negative (7/176). Approximately $400 \mathrm{bp}$ of the PCR product from five of these samples were sequenced and all sequences were $99 \%$ or $100 \%$ equal to C. jejuni. The diagnostic specificity for the comparison of the PCR to culture by selective enrichment was 0.96 with a level of agreement of 0.96 . 
Table 3

Comparison of PCR results and culture for the detection of the Campylobacter in marinated and non-marinated poultry products after enrichment

\begin{tabular}{llcr}
\hline PCR & \multicolumn{2}{l}{ Culture } & \\
\cline { 2 - 4 } & Positive & Negative & Total \\
\hline Positive & 17 & 7 & 24 \\
Negative & 1 & 169 & 170 \\
Total & 18 & 176 & 194 \\
\hline
\end{tabular}

Table 4

Comparison of detection limit between culture methods and PCR methods

\begin{tabular}{lllll}
\hline $\begin{array}{l}\text { Size of the inoculum in spiked } \\
\text { samples }(\mathrm{cfu} / \mathrm{ml})\end{array}$ & $\begin{array}{l}\text { Direct } \\
\text { culture }\end{array}$ & $\begin{array}{l}\text { Direct } \\
\text { PCR }\end{array}$ & $\begin{array}{l}\text { Enrichment } \\
\text { culture }\end{array}$ & $\begin{array}{l}\text { Enrichment } \\
\text { PCR }\end{array}$ \\
\hline $7 \times 10^{5}$ & + & + & + & + \\
$7 \times 10^{4}$ & + & + & + & + \\
$7 \times 10^{3}$ & + & + & + & + \\
$7 \times 10^{2}$ & + & + & + & + \\
70 & + & - & + & + \\
7 & - & - & + & + \\
0.7 & - & - & + & + \\
\hline
\end{tabular}

\subsection{Specificity of the PCR assays}

The specificity of the C412F-16S rRNA-campR2 primer set was tested against a panel of Campylobacter and non-Campylobacter DNA templates (Table 1). The PCR assay detected C. jejuni, C. coli, C. lari, $C$. upsaliensis, $C$. helveticus, and C. hyointestinalis, but none of the other Campylobacter species tested. No signal was observed for any of the Arcobater, Helicobacter, or other non-Campylobacter species tested. The specificity of the MD16S1-MD16S2 PCR assay was tested by Denis et al. (1999). The assay detected all tested strains of $C$. jejuni, $C$. coli and $C$. hyoilei, but gave no reaction for non-Campylobacter strains tested in the study (Denis et al., 1999).

\subsection{Comparison of the detection limit between the culture and PCR method}

Table 4 shows the results of direct and enrichment culture of spiked samples as well as PCR performed on DNA isolated directly from the same spiked samples or from the enrichments culture of the samples. The detection limit of both enrichment culture and enrichment PCR was less than $1 \mathrm{cfu} / \mathrm{ml}$ of sample rinse, while the detection limit of direct culture was $70 \mathrm{cfu} / \mathrm{ml}$. For the direct PCR detection the limit was $700 \mathrm{cfu} / \mathrm{ml}$ of sample rinse.

\section{Discussion}

The low prevalence of Campylobacter in retail poultry products observed in the present study is consistent with earlier studies carried out in Finland (Hänninen et al., 2000; Anonymous, 2006a). However, these findings are relatively low compared to other countries. In Germany, Luber et al. (2005) reported the occurrence of $67.6 \%$ and $11.3 \%$ Campylobacter on the surface and in the deep muscle tissue of broiler legs respectively. Alter et al. (2004) detected $6.2 \%$ and 30.3\% Campylobacter in 419 turkey and 198 chicken retail products respectively. Nielsen et al. (2006) investigated Danish retail poultry products, including domestic and imported meat, and found Campylobacter in $38.7 \%$ of 460 chicken and in $27.5 \%$ of 204 turkey products. Dominguez et al.
(2002) reported 49.5\% Campylobacter occurrence in 198 chicken meat samples from the Spanish retail market. The low occurrence of Campylobacter in Finnish retail poultry products obviously reflects the low prevalence of the organisms in the broiler slaughter batches in Finland. Prevalences between 2.9\% and 7.4\% have been reported from examination of all broiler slaughter batches during the summer months, when the prevalence is highest in Finland (Perko-Mäkela et al., 2002; Anonymous 2006b, c).

In August, there was a peak with a $28.9 \%$ prevalence of Campylobacter (Fig. 1). A seasonal variation in chicken flocks has also been observed in the other Nordic countries (Wedderkopp et al., 2000; Bang et al., 2003; Hansson et al., 2004; Hofshagen and Kruse, 2005) and the Netherlands (Bouwknegt et al., 2004). In contrast, Logue et al. (2003) discovered Campylobacter more frequently in the cooler months (winter and early spring) in the US. They suggested that the difference in the seasonal occurrence of Campylobacter in poultry might be associated with the geographical locations where sampling occurred.

In the present study, Campylobacter was also detected in marinated poultry products with a prevalence of $21.1 \%$ and $9.5 \%$ for turkey and chicken products respectively. Atanassova et al. (2007) reported six out of 16 marinated turkey products from German retail shops as Campylobacter positive. Perko-Mäkelä et al. (2000) studied the survival of $C$. jejuni in plain marinade and in both marinated and non-marinated chicken drumsticks and meat slices. In the marinade, a decrease of the inoculated $C$. jejuni level was observed; however, there was no difference between the marinated and non-marinated meat. The authors concluded that marinating may not have an effect on the survival of Campylobacter. This may be due to the buffering capability of meat quickly neutralizing the $\mathrm{pH}$ of the acidic marinade (Perko-Mäkelä et al., 2000). However, in the present study no Campylobacter was detected in 22 marinated sliced chicken products. All these samples were from meat of foreign origin. Foreign meat is frozen when imported to Finland which could be the reason that these samples were negative for Campylobacter.

The diagnostic specificity in the comparison between the PCR and the cultural detection by selective enrichment was 0.96 with a level of agreement of 0.96 . This is a good agreement between the two methods. One sample of 18 gave a negative result in PCR when the result of the culture method was positive. This falsenegative result may be explained by the fact that the size of the subsample used for the culture method is larger than in the PCR method; $25 \mathrm{ml}$ of the rinsing fluid enriched in $225 \mathrm{ml}$ Bolton broth compared to $1 \mathrm{ml}$ for DNA extraction in the PCR method. However, for this reason comparing direct PCR with enrichment culture may be difficult.

Seven samples gave a positive result with PCR after enrichment, whereas the culture result was negative. However, sequencing of the PCR product from five of these samples gave sequences being $99 \%$ or $100 \%$ equal to $C$. jejuni. The reason for these negative culture results might be the abundant growth of the background flora on mCCDA plates. Six of the seven samples were products with skin likely to contain more contaminating flora than samples without skin (Josefsen et al., 2003). Background flora was detected in $5 \%$ of all samples and sometimes it was so abundant that it made the detection of Campylobacter impossible. Mateo et al. (2005) reported the same problem with overgrowth in $52.9 \%$ of 68 samples and identified Escherichia coli in some cases. However, they used Preston broth for selective enrichment. Bolton broth proved to be the best compromise between the inhibition of competitors and growth of Campylobacter (Baylis et al., 2000), but this may depend on the material investigated (Josefsen et al., 2003; Tangvatcharin et al., 2005). 


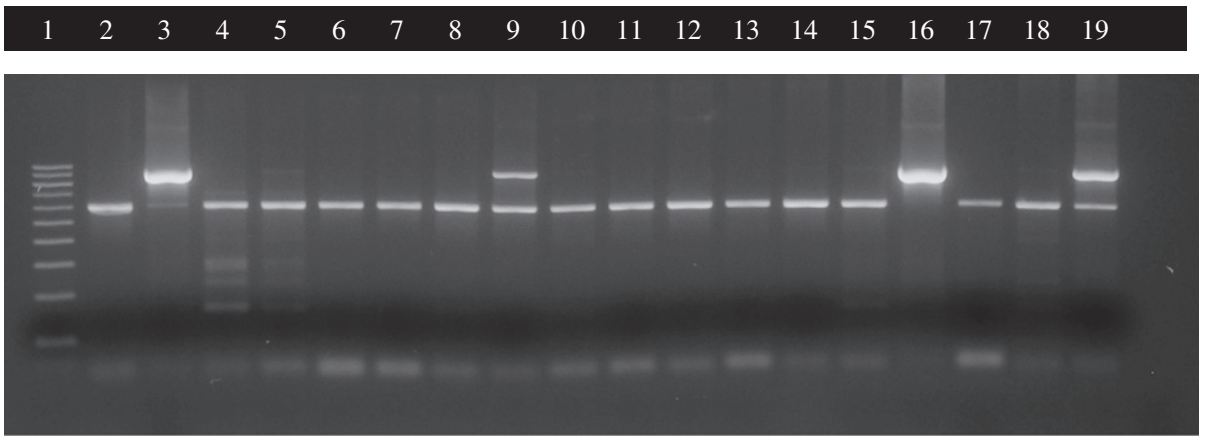

Lane 1: 100 bp-DNA molecular weight marker; lane 2: PCR-negative control (internal control); lane 3: PCR-positive control (857 bp); lanes 4 - 8: Campylobacter-negative samples; lane 9: Campylobacterpositive sample; lanes $10-15$ : Campylobacter-negative samples; lane 16: Campylobacter-positive sample; lanes 17 - 18: Campylobacter-negative samples; lane 19: Campylobacter-positive sample.

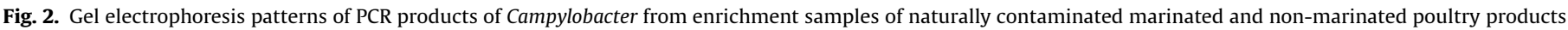
at the Finnish retail level using C412F and 16S rRNA campR2 primers.

Susceptibility to inhibitory substances, which can be found in high levels in foods, is a great disadvantage of PCR (Abu Al-Soud and Radstrom, 1998; Abu Al-Soud and Radstrom, 2000; Rossen et al., 1992). Lilja and Hänninen (2001), studying marinated chicken products and using the Buoyant Density Centrifugation (BDC) method for sample preparation, reported problems probably caused by emulsifiers used in the oil-spice. Rossen et al. (1992) used a pre-treatment step with hot sodium hydroxide/ sodium dodecyl sulfate to reduce the effect of food inhibitory substances. In the present study, a pre-centrifugation step was performed in order to exclude most of the lipids and fat from the marinade and the chicken skin. As DNA isolation was performed manually with a DNA isolation kit for automated DNA isolation, further optimization compared to manufacturer's instructions was necessary to make the manual DNA isolation as sensitive as the automated isolation. Vigorous vortexing of the samples in lysis buffer was found to be the most important step. To optimize DNA isolation from marinated poultry products, one possibility could be to add fat digesting enzymes to the bacterial pellet just prior to DNA isolation. A nested PCR method could lower the detection limit, however, when the number of Campylobacter is very low, it is a question of statistics if any bacteria will appear in a $1 \mathrm{ml}$ sample.

To control the PCR reaction in the different samples studied in this assay, an internal control PCR was run simultaneously with the target DNA (Fig. 2). In both PCR reactions, performed on DNA isolated directly from the samples and on DNA isolated from the enrichment media, the internal control gave a band of same intensity showing no evidence of inhibition of the PCR reaction. However, the detection limit of the direct PCR was about $700 \mathrm{cfu} /$ $\mathrm{ml}$ (Table 4). This is high compared to other direct PCR assays for Campylobacter. Lund et al. (2003) reported a detection limit of approximately $40 \mathrm{cfu} / \mathrm{ml}$ in fecal material and Yang et al. (2003) of $100 \mathrm{cfu} / \mathrm{ml}$ in the same material using a real-time PCR assay. As inhibition of the PCR reaction does not seem to be the problem, it may also be possible that Campylobacter are preferably located in the fatty part of the sample and as this part is removed before DNA isolation many bacteria might be lost. On the other hand, the fat and or protein still present in a sample after pre-treatment could interfere with DNA isolation. As the detection limit of the present direct PCR was too high compared to the normally quite low amount of Campylobacter in food and retail poultry samples, it was necessary to perform a combination of enrichment and PCR assay.

In the present study, we used a new combination of primers (C412F and 16S rRNA campR2). A tendency was seen that this primer set captured more of the samples that were culture negative and negative with the MD16S1 and MD16S2 primers (results not shown). However, the differences were not statistically significant.

\section{Conclusions}

The PCR method used shortens time compared to microbiological analyses and can be therefore used for detection of Campylobacter spp. in poultry products. However, enrichment of the samples is necessary due to the low occurrence of Campylobacter spp. in Finnish poultry products at the retail level.

\section{Acknowledgment}

The authors wish to thank Katariina Uutela for her excellent assistance. The practical assistance from Heikki Ahola and the staff of Finnish Food Safety Authority Evira, Seinäjoki Research Unit is gratefully acknowledged.

\section{References}

Abu Al-Soud, W., Radstrom, P., 1998. Capacity of nine thermostable DNA polymerases to mediate DNA amplification in the presence of PCR-inhibiting samples. Appl. Environ. Microbiol. 64, 3748-3753.

Abu Al-Soud, W., Radstrom, P., 2000. Effects of amplification facilitators on diagnostic PCR in the presence of blood, feces, and meat. J. Clin. Microbiol. 38, 4463-4470.

Alter, T., Gürtler, M., Gaull, F., Johne, A., Fehlhaber, K., 2004. Comparative analysis of the prevalence of Campylobacter spp. in retail turkey and chicken meat. Arch. Lebensmittelhyg. 55, 49-72.

Anonymous, 2005. Register of Infectious Diseases, supplied by the National Public Health Institute (KTL). 〈http://www.ktl.fi/portal/suomi/osastot/infe/julkaisut/ tartuntataudit_suomessa_vuonna_2005/ http://www.ktl.fi/ttr $\rangle$

Anonymous, 2006a. Trends on sources of zoonoses, zoonotic agents and antimicrobial resistance in the EU in 2004. EFSA J. 2005-310, 98-100 <http:// www.efsa.eu.int/science/monitoring_zoonoses/reports/1277_en.html $\rangle$.

Anonymous, 2006b. EFSA Zoonosis Monitoring. Finland. The report referred to in Article 5 of Directive 92/117/EEC. Trends and sources of zoonoses and zoonotic agents in humans, foodstuffs, animals and feedingstuffs including information on foodborne outbreaks and antimicrobial resistance in zoonotic agents in 2004. 〈http://www.efsa.europa.eu/EFSA/DocumentSet/zoon_report_2004_ finland_edited2.pdf $\rangle$.

Anonymous, 2006c. EFSA Zoonosis Monitoring. Finland. The report referred to in Article 9 of Directive 2003/99/EC. Trends and sources of zoonoses and zoonotic agents in humans, foodstuffs, animals and feedingstuffs including information on foodborne outbreaks and antimicrobial resistance in zoonotic agents in 2005. <http://www.efsa.europa.eu/EFSA/DocumentSet/zoon_report_2005_ Finland $\rangle$. 
Atanassova, V., Reich, F., Beckmann, L., Klein, G., 2007. Prevalence of Campylobacter spp. in turkey meat from a slaughterhouse and in turkey meat retail products. FEMS Immunol. Med. Microbiol. 49, 141-145.

Bang, D.D., Nielsen, E.M., Knudsen, K., Madsen, M., 2003. A one-year study of Campylobacter carriage by individual Danish broiler chickens as the basis for selection of Campylobacter spp. strains for a chicken infection model. Epidemiol. Infect. 130, 323-333.

Baylis, C.L., MacPhee, S., Martin, K.W., Humphrey, T.J., Betts, R.P., 2000. Comparison of three enrichment media for the isolation of Campylobacter spp. from foods. J. Appl. Microbiol. 89, 884-891.

Björkroth, J., 2005. Microbial ecology of marinated meat products. Meat Sci. 70, 477-480.

Bouwknegt, M., van de Giessen, A.W., Dam-Deisz, W.D., Havelaar, A.H., Nagelkerke, N.J., Henken, A.M., 2004. Risk factors for the presence of Campylobacterr spp. in Dutch broiler flocks. Prev. Vet. Med. 62, 35-49.

Denis, M., Soumet, C., Rivoal, K., Ermel, G., Blivet, D., Salvat, G., Colin, P., 1999. Development of a m-PCR assay for simultaneous identification of Campylobacter jejuni and C. coli. Lett. Appl. Microbiol. 29, 410-416.

Denis, M., Refrégier-Petton, M.-J., Laisney, G., Ermel, G., Salvat, G., 2001. Campylobacter contamination in French chicken production from farm to consumers. Use of a PCR assay for detection and identification of Campylobacter jejuni and Campylobacter coli. J. Appl. Microbiol. 91, 255-267.

Dominguez, C., Gómez, I., Zumalacarregui, J., 2002. Prevalence of Salmonella and Campylobacter in retail chicken meat in Spain. Int. J. Food Microbiol. 72, $165-168$.

Evans, M.R., Lane, W., Frost, J.A., Nylen, G., 1998. A campylobacter outbreak associated with stir-fried food. Epidemiol. Infect. 121, 275-279.

Evans, M.R., Ribeiro, C.D., Salmon, R.L., 2003. Hazards of healthy living: bottled water and salad vegetables as risk factors for Campylobacter infection. Emerg. Infect. Dis. 9, 1219-1225.

Gibello, M.M., Blanco, M.A., Moreno, M.T., Cutuli, A., Domenech, L., Domínguez, C., Fernández-Garayzábal, J.F., 1999. Development of a PCR assay for detection of Yersinia ruckeri in tissues of inoculated and naturally infected trout. Appl. Environ. Microbiol. 65, 346-350.

Hänninen, M.-L., Perko-Mäkelä, P., Pitkälä, A., Rautelin, H., 2000. A three-year study of Campylobacter jejuni genotypes in humans with domestically acquired infections and in chicken samples from the Helsinki area. J. Clin. Microbiol. 38, 1998-2000.

Hansson, I., Engvall, E.O., Lindblad, J., Gunnarson, A., Vågsholm, I., 2004. The Campylobacter surveillance program for broilers in Sweden, July 2001-June 2002. Vet. Rec. 155, 193-196.

Hofshagen, M., Kruse, H., 2005. Reduction of Campylobacter spp. in broilers in Norway after implementation of an action plan. J. Food Prot. 68, 2220-2223.

Josefsen, M.H., Lubeck, P.S., Aalbaek, B., Hoorfar, J., 2003. Preston and ParkSanders protocols adapted for semi-quantitative isolation of thermotolerant Campylobacter from chicken rinse. Int. J. Food Microbiol. 80, 177-183.

Lilja, L., Hänninen, M.-L., 2001. Evaluation of a commercial automated ELISA and PCR-method for the rapid detection and identification of Campylobacter jejuni and C. coli in poultry products. Food Microbiol. 18, 205-209.

Linton, D., Owen, R.J., Stanley, J., 1996. Rapid identification by PCR of the genus Campylobacter and five Campylobacter species enteropathogenic for man and animals. Res. Microbiol. 147, 707-718.

Logue, C.M., Sherwood, J.S., Elijah, L.M., Olah, P.A., Dockter, M.R., 2003. The incidence of Campylobacter spp. on processed turkey from processing plants in the midwestern United States. J. Appl. Microbiol. 95, 234-241.

Luber, P., Bartelt, E., 2007. Enumeration of Campylobacter spp. on the surface and within chicken breast fillets. J. Appl. Microbiol. 102, 313-318.

Luber, P., Scherer, K., Bartelt, E., 2005. Kontamination von Hähnchenkeulen mit Campylobacter spp. Fleischwirt 6, 93-96.

Lund, M., Madsen, M., 2006. Strategies for the inclusion of an internal amplification control in conventional and real-time PCR detection of Campylobacter spp. in chicken fecal samples. Molec. Cell Probes 20, 92-99.
Lund, M., Wedderkopp, A., Waino, M., Nordentoft, S., Bang, D.D., Pedersen, K., Madsen, M., 2003. Evaluation of PCR for detection of Campylobacter in a national broiler surveillance programme in Denmark. J. Appl. Microbiol. 94, 929-935.

Lund, M., Nordentoft, S., Pedersen, K., Madsen, M., 2004. Detection of Campylobacter spp. in chicken fecal samples by real-time PCR. J. Clin. Microbiol. 42, 5125-5132.

Martin, S.W., Meek, A.H., Willberg, P., 1997. In: Mateo, E., Carcamo, J., Urquijo, A (Eds.), Veterinary Epidemiology, Principles and Methods. I.A. Iowa State University Press.

Mateo, E., Cárcamo, J., Urquijo, M., Perales, I., Fernandez-Astorga, A., 2005 Evaluation of a PCR assay for the detection and identification of Campylobacter jejuni and Campylobacter coli in retail poultry products. Res. Microbiol. 156, 568-574.

National Committee of Food Analyses, 2007. Thermotolerant Campylobacter. Detection, semi-quantitative and quantitative determination in foods and drinking water, 3rd ed. NCFA method no. 119,

Nielsen, E.M., Fussing, V., Engberg, J., Nielsen, N.L., Neimann, J., 2006. Most Campylobacter subtypes from sporadic infections can be found in retail poultry products and food animals. Epidemiol. Infect. 134, 758-767.

Perko-Mäkelä, P., Koljonen, M., Miettinen, M., Hänninen, M.-L., 2000. Survival of Campylobacter jejuni in marinated and non-marinated chicken products. J. Food Saf. 20, 209-216.

Perko-Mäkela, P., Hakkinen, M., Honkanen-Buzalski, T., Hänninen, M.-L., 2002. Prevalence of campylobacters in chicken flocks during the summer of 1999 in Finland. Epidemiol. Infect. 129, 187-192.

Philipps, C.A., 1998. The isolation of Campylobacter spp. from modified atmosphere packaged foods. Int. J. Environ. Health Res. 8, 215-221.

Potter, R.C., Kaneene, J.B., Hall, W.N., 2003. Risk factors for sporadic Campylobacter jejuni infections in Rural Michigan: a prospective case-control study. Am. J. Publ. Health 93, 2118-2123.

Rautelin, H., Hänninen, M.-L., 2000. Campylobacters: the most common bacterial enteropathogens in the Nordic countries. Ann. Med. 32, 440-445.

Rossen, L., Norskov, P., Holmstrom, K., Rasmussen, O.F., 1992. Inhibition of PCR by components of food samples, microbial diagnostic assays and DNA-extraction solutions. Int. J. Food Microbiol. 17, 37-45.

Sallam, K.I., 2007. Prevalence of Campylobacter in chicken and chicken by-products retailed in Sapporo area, Hokkaido, Japan. Food Control 18, 1113-1120.

Samuel, M.C., Vugia, D.J., Shallow, S., Marcus, R., Segler, S., McGivern, T., Kassenborg, H., Reilly, K., Kennedy, M., Angulo, F., Tauxe, R.V., 2004. Epidemiology of sporadic Campylobacter infection in the United States and declining trend in incidence, FoodNet 1996-1999. Clin. Infect. Dis. 38 S165-S174.

Schönberg-Norio, D., Takkinen, J., Hänninen, M.-L., Katila, M.-L., Kaukoranta, S.-S., Mattile, L., Rautelin, H., 2004. Swimming and Campylobacter infections. Emerg. Inf. Dis. 10, 1474-1477.

Schönberg-Norio, D., Sarna, S., Hänninen, M.-L., Katila, M.-L., Kaukoranta, S.-S. Rautelin, H., 2006. Strain and host characteristics of Campylobacter jejuni infections in Finland. Clin. Microbiol. Infect. 12, 754-760.

Smith, R.D., 1995. Veterinary Clinical Epidemiology. CRC Press, Inc, Florida.

Tangvatcharin, P., Chanthachum, S., Kopaiboon, P., Inttasungkha, N., Griffiths, M.W., 2005. Comparison of methods for the isolation of thermotolerant Campylobacter from poultry. J. Food Prot. 68, 616-620.

Wedderkopp, A., Rattenborg, E., Madsen, M., 2000. National surveillance of Campylobacter in broilers at slaughter in Denmark in 1998. Avian Dis. 44, 993-999.

Wong, T.L., Devane, M.L., Hudsonm, J.A., Scholes, P., Savill, M.G., Klena, J.D., 2004. Validation of a PCR method for Campylobacter detection on poultry packs. Br Food J. 106, 642-650.

Yang, C., Jiang, Y., Huang, K., Zhu, C., Yin, Y., 2003. Application of real-time PCR for quantitative detection of Campylobacter jejuni in poultry, milk and environmental water. FEMS Immunol. Med. Microbiol. 38, 265-271. 